Public Policy \&

Aging Report ${ }^{\circ}$

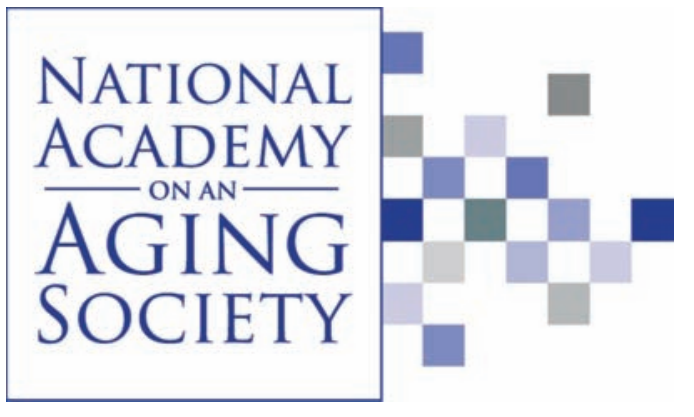

Spring 2013

Volume 23, Number 2
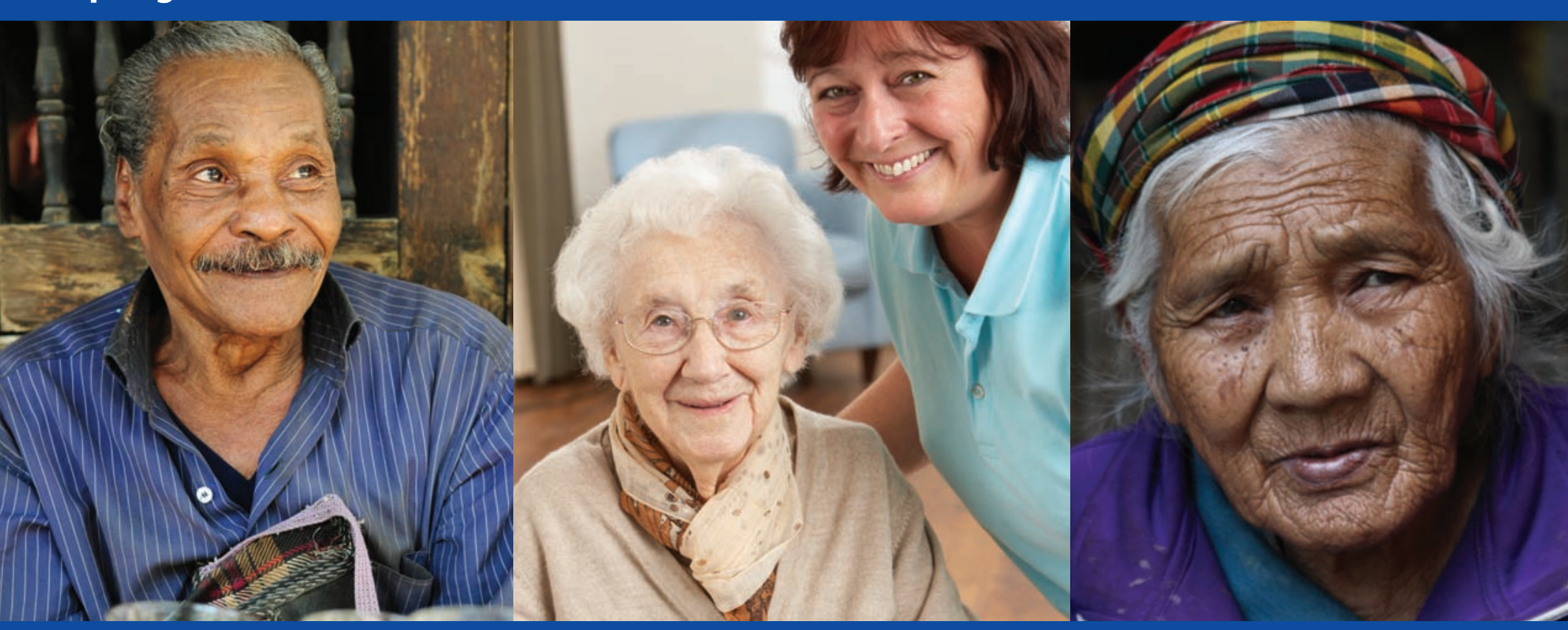

The Global Impact of Aging: The Oldest Old
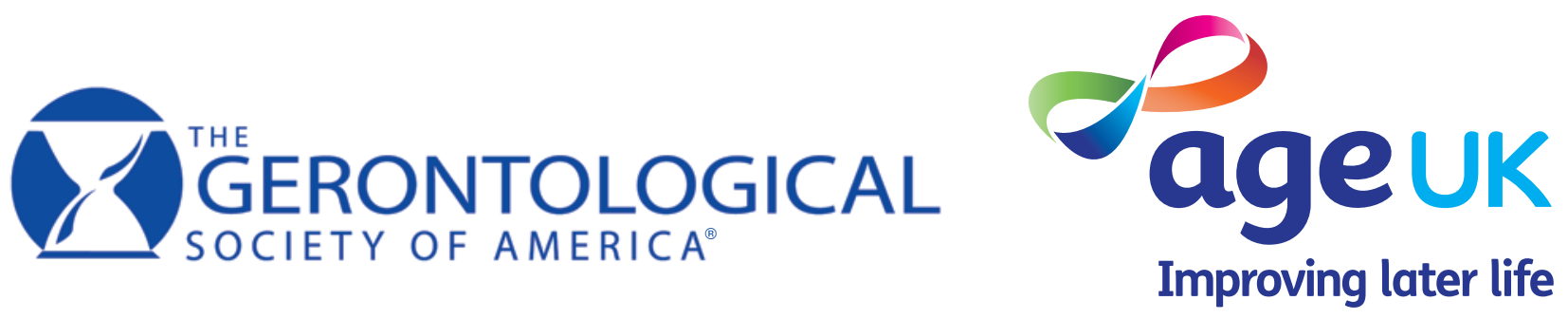


\section{An Older, Wiser World: Some Economic Consequences of Population Aging}

\section{David K. Foot}

Population aging is now a well-recognized feature in nations around the globe. The world's 65 -and-older population is projected to triple by midcentury, from 516 million in 2009 to 1.53 billion in 2050, and the world's 85 -and-older population is projected to increase more than fivefold, from 40 million to 219 million (U.S. Census Bureau, 2009).

Although population aging has many determinantssuch as better health and longer life expectancy-the common and most dominant characteristic that countries with aging populations share is sustained belowreplacement fertility. An average of 2.1 children per woman (to account for women who do not give birth) is considered sufficient to sustain a population through internal growth. Many countries now have a lower fertility rate. The United States has one of the highest fertility rates (1.9) in the developed world - but even replacement fertility would not be sufficient to prevent the U.S. population from aging, because rising life expectancy increases both the median age and the proportion of older adults in the population.

Some of the changes caused by population aging pose difficulties to society; others are beneficial. For example, an older society requires fewer goods per capita-a situation detrimental to the business of manufacturing and selling goods. But an aging society requires many more services, and that means new business opportunities. An aging population can be expected to reduce spending on education but accelerate spending on health care, because older people require less formal education but more health care than younger people (Foot \& Gomez, 2006).

Slower workforce growth is inevitable in aging populations; where fertility is below replacement level, the shrinking number of children will inevitably produce smaller worker and consumer populations. Given that workforce growth historically has been the crucial determinant of a country's economic growth, it is not surprising that government and business leaders fear a decline in material living standards if their country's working-age population does not keep pace with the world's growing economies. However, countries with slow-growing or even shrinking populations do not automatically experience declines in material living standards. As long as economic growth exceeds population growth, even if both are negative, per capita incomes increase. Furthermore, reducing the growth (and especially the size) of the human footprint has environmental benefits.
How might countries with older populations offset slower workforce growth? One strategy is to let countries with younger populations specialize in low-wage, laborintensive jobs while they develop a highly skilled, technology-based workforce at home. In short, nations can compensate for a larger population of retired people by enhancing workforce productivity with the best technology. In addition, promoting other measuressuch as flexible working hours, elder care, and prorated benefits for part-time workers-and eliminating age discrimination, as well as policies that discourage partial retirement, would likely increase older people's participation in the labor force (Foot \& Venne, 2011).

Countries with older population profiles also need to explore changes to their taxation policies. With relatively fewer workers, government will have to move gradually from taxation of labor income to taxation of capital income. In a society with large numbers of people in their prime earning and spending years, a tax system based on income and sales taxes makes sense. Such a system will not make as much sense for a future in which more income will be generated by technology and capital. A country with an aging population must consider increased taxes on dividends, capital gains, and corporate profits, as well as taxes on foreign exchange transactions and such, which currently are not taxed.

That the globe is graying lies beyond doubt, but the reality of this demographic fact is a far cry from the gloom-and-doom portrait painted by countless pundits who exaggerate the implications of increased longevity and lower birth rates worldwide. If the world's nations prepare for the coming demographic shift with creative policies, everyone can both enjoy its benefits and manage its inevitable challenges.

David K. Foot, PhD, is professor emeritus, Department of Economics, University of Toronto.

\section{References}

Foot, D. K. \& Gomez, R. (2006). Population ageing and sectoral growth: The case of the U.K., 2006-2026. Oxford Journal of Business and Economics, 5(1), 85-94.

Foot, D. K. \& Venne, R. A. (2011). The long goodbye: Age, demographics, and flexibility in retirement. Canadian Studies in Population, 38(3-4), 59-74.

U.S. Census Bureau. (2009, June). Census Bureau reports world's older population projected to triple by 2050. Retrieved from http://www.census.gov/newsroom/ releases/archives/international_population/cb09-97.html 